\title{
IMPACT OF EXTERNAL DEBT ON ECONOMIC GROWTH IN NIGERIA
}

\author{
Ajuh, Ali Iteh ${ }^{\mathbf{1}}$, Edith Oyeanu ${ }^{\mathbf{1}}$ \\ ${ }^{1}$ Department of Accountancy, Faculty of Business Administration, \\ University of Nigeria, Enugu Campus, Enugu, Nigeria
}

\begin{abstract}
This paper investigated the impact of external debt on economic growth in Nigeria from 1985 to 2018 using vector autoregressive (VAR) approach. The empirical results revealed that both external debt stock and external debt service exerted a negative and significant impact on economic growth. These outcomes entailed that when external debt stock changed by one-unit, economic growth declined by 0.495 unit. On the other hand, when external debt services changed by one-unit, economic growth declined by 0.017 unit. We concluded that external debt stock had been an impediment to economic growth in Nigeria over the period under study. We therefore recommended that policy makers should adhere strictly to the appropriate use of debt through efficient investment to foster growth and avoid excessive debt accumulation.
\end{abstract}

Keywords: External debt stock, External debt service, Economic growth, Vector autoregressive.

Cite this Article: Ajuh, Ali Iteh and Edith Oyeanu, Impact of External Debt on Economic Growth in Nigeria, International Journal of Mechanical Engineering and Technology (IJMET), 12(7), 2021, pp. 49-57.

https://iaeme.com/Home/issue/IJMET?Volume=12\&Issue=7

\section{INTRODUCTION}

Though Nigeria has not been alone in experiencing escalating government indebtedness but in comparison with other Sub-Sahara Africa, Nigerian debt to GDP has been on the high side (Asogwa, 2005). An escalating debt profile may present serious obstacle to a nation's path to economic growth and development. The cost of servicing the debt may expand beyond the capacity of the economy to cope thereby impacting negatively on the ability to achieve the desired fiscal and monetary policy objectives. Furthermore, a rising debt burden may constrain the ability of government to undertake more productive investment programmes in infrastructure, education and public health (Soludo, 2003). The recent movement of attention from external borrowing to domestic borrowing due to limited access to external finance, indicates that Nigerian domestic debt is bound to increase continuously and may grow beyond limits. It is against this background that the study seeks to investigate the impact of public debt on economic growth in Nigeria. 
Tajudee (2012) opined that borrowing within the country is better than borrowing outside the country because it will help to stimulate the growth of the economy since the repayment of the principal and interest would lead to increase in the total output in the country when well utilized. But when the country borrows outside the country she would need more money for repayment of the debt as result of exchange rate disparity. This can hinder the rate of growth that the debt, would have brought to the economy.

Therefore he advised that internal borrowing is better than external borrowing for any government in order to boost economic growth. In spite of how attractive foreign borrowing may look, governments may possibly still look toward domestic because of the following benefit of domestic borrowing. (i) The beneficiary country growth performance and budget can be evaluated by the aid agencies and the provision of oversea funding may be determined by the same body. (ii) International assistance comes frequently to enable the government fund projects both capital and recurrent according to the donors support. Therefore, domestic savings would help to bring low budget deficits of governments with large recurrent budget deficits in order to bridge the gap. Borrowing within the country is helpful in accomplishing the target of the monetary authority especially in the nation with surplus balance of payment (Jakob, 2004).

While Jose, Ferreira-Lopes \& Tiago, (2012) in their study are of the opinion that judicious use of public debt resources whether external or domestic is what will determine its impact on economic growth of any nations. Hence borrowing within and outside the counties is very useful when employed into productive investment such as investment in agriculture, and other lucrative sector which will boast the economy. When money borrowed is not well utilized, it will not bring about the necessary contribution to the economy.

\section{LITERATURE REVIEW}

The issue of public debt and its relationship with macroeconomic variables has brought about an increasing literature regarding the determinants of public debt burden and its impact on the economy as well as the policy implications. Some of the empirical works reviewed in this section borders on analysis carried out between public debt and its impact on economic growth, prices (inflation), crowding out of private sector and interest rates.

A study by Ekperiware and Oladeji (2012) examined the effect of external debt relief on economic growth in Nigeria using regression technique on quarterly time series of external debt, external debt service and real gross domestic product. Applying Chow- test to the regression result they found that there was a structural break in the relationship between economic growth and external debt in Nigeria during the period 1975 to 2005. The study concluded that the external debt relief made more resources available for economic growth in Nigeria and recommended a shift towards discretional concessional borrowing. It also identified external debt relief as a good option for poor unsustainable indebted countries as a way of making resources available for economic growth with the real sector being the focal point where value is created rather than impeding it with mismanagement and servicing debt.

Obademi (2012) used the ordinary least squares (OLS) technique in an augmented Cobb Douglas model in analyzing the impact of public debt on economic growth in Nigeria. The variables used were the external debt, domestic debt, total debt and budget deficit. He found that the impact of debt on economic growth was negative and quite significant in the long-run though in the short-run the impact was useful. He concluded that though the impact of borrowed funds on the Nigerian economy was positive in the short-run, its impact in the long-run depressed the economy as a result of inefficient debt management.

In another attempt to study the impact of external debt management on macro-economic performance in Nigeria, Ezike and Mojekwu (2011) applied the OLS technique on real GDP, total external debt stock and debt service ratio. Their results revealed that foreign capital inflow 
was positive as expected while debt service/export ratio was negative as expected. This was because debt capital adds to capital formation and positively impacted on economic growth. On the other hand, debt-service ratio reflects capital outflow and consequently deteriorates the performance of a country and thus reduces real GDP. It also confirms the theoretical expectations that debt service/export ratio diverts resources away from the debtor country. Since total debt stock depicts a positive relationship in the results instead of a negative relationship and statistically significant at all the levels, they therefore concluded that total debt stock, less debt service, still leaves a robust positive balance, to enhance capital accumulation that positively impacts economic growth.

Udoka and Ogege (2012) examined the extent of public debt crisis and its consequences on economic development using data on the Nigerian economy for the period 1970 to 2010 . They employed the error correction modeling framework with co-integration techniques to test the relationship between per-capita GDP and other macroeconomic variables (foreign reserve, debt stock, investment, debt service payment). The test revealed that political instability may reduce the rate of development and other independent variables were responsible for the underdevelopment of the country. Hence, they recommended that, to avoid the crisis of economic development in Nigeria, public debt should be reduced to minimal level.

Tajudeen (2012) examined the causal nexus between public debt and economic growth in Nigeria between 1970 and 2010 using a Vector Autoregressive (VAR). The variables used in the study were tested for stationarity using the Augmented Dickey Fuller and Philip Perron test. The result showed that the variables were stationary at first differencing. Co-integration test was also performed and the result revealed the presence of co-integration between public debt and economic growth. The co-integration results showed that public debt and economic growth have long run relationship. The findings of the VAR model revealed that there is a bi-directional causality between public debt and economic growth in Nigeria. The paper concluded that public debt and economic growth have long run relationship, and they are positively related if the government is sincere with the loan obtained and use it for the development of the economy rather than channel the funds to their personal benefit.

Mba, Yuni \& Oburota (2013) analysed the importance of domestic debt on economic growth of Nigeria. The objective of the study was to investigate the relationship between government domestic debt and economic growth and policy that is likely to improve private sector investment and break growth resistance problem and empirically determine the relationship between domestic debt and some macroeconomic variables. The study employed the error correction model procedures following an examination of properties of the time series using unit root and co-integration test. Findings showed that domestic debt and credit have a significant and direct relationship with GDP and that debt servicing had inverse relationship with GDP and also government expenditure had a direct but not significant relationship with GDP. The implication of the findings was that domestic debt should be invested in productive sector of the economy and more specifically in the real sector and further productivity gain will be achieved in the improvement on capital project expenditure.

Essien, Agboegbulem, Mba \& Onumonu (2016) examined the impact of public sector borrowings on prices, interest rates, and output in Nigeria. It utilized a Vector Autoregressive framework, the Granger causality test, impulse response, and variance decomposition of the various innovations to study the impact. It found that shock to external debt stock increases prime lending rate, but with a lag. However, the level of external and domestic debt over the period of this study had no significant impact on the general price level and output.

Elom-Obed, Odo, Elom \& Anoke (2017) analyzed the relationship between public debt and economic growth in Nigeria from 1980-2015. The study adopted Vector Error Correction Model (VECM) approach of econometric data analysis. The variables used in the study included 
real gross domestic product (RGDP), foreign debt, domestic debt and domestic private savings. The results of the study indicated that: (i) External debt had significant negative impact on economic growth within the period under study. (ii) Domestic debt (DMD) had significant negative relationship with economic growth within the period under consideration. (iii) External debt and domestic debt granger cause RGDP in Nigeria with causality running from external debt and domestic debt to RGDP. The implication of this result is that the negative correlation between debt stocks (external debt and domestic debt) and economic growth which is contrary to apprior expectation may be highlighting the misappropriation and wrong application (corrupt practices) of the borrowed funds. Based on the findings, the study recommends therefore that (i) Government should reduce external debt and the ones obtained should be strictly used for purposes intended to ensure positive effect. (ii) Government should cut down on domestic borrowing and ensure that the already borrowed funds are applied for purposes intended to ensure positive effect and through growth. (iii) With the evidence of negative causality running from both external and domestic debt stock to economic growth (RGDP) suggests that government should cut down in both borrowings to ensure economic stability and sustainable growth.

Akhanolu, Babajide, Akinjare, Oladeji \& Osuma (2018) focused on the Nigerian government's debt and its impact on economic growth from 1982-2017 using the two-stage least square regression. For the first equation, both internal and external debt and their lags were regressed against GDP, the result showed that external debt negatively impacts the economy while internal debt positively does the same. For the second equation, GDP, total savings deposits in the Nigerian deposit money banks and capital expenditure were regressed against internal debt, the result showed that all the variables have significant relationship with internal debt. The study thus, recommended that first; Corruption of borrowed funds should be tackled at all cost and also, government should minimize external borrowing, since, it impacts the economy negatively.

\section{DATA AND METHODOLOGY}

The source of data for this study relies completely on secondary data. These are data that have been collected, processed and exist in literatures, articles and bulletins; published and unpublished. Annual data for this study was obtained from World Bank's World Development Indicators (WDI) for the period spanning 1986-2017. We tested our variables for stationarity using the Augmented Dickey-Fuller (ADF) unit root test. Based on the outcome, we employed the vector autoregressive (VAR) estimation technique in analyzing our model. We also subjected our data set to descriptive statistics and analysis.

\subsection{Description of Research Variables}

Real Gross Domestic Product (RGDP): This according to economists refer to the total worth of product produced in the economy in a particular year valued at market prices as adjusted for price changes plus the imputed value of the economy's produced goods and services that do not pass through the market channel minus net income from abroad. The Real GDP is calculated as the current price of value of final goods and service divided by the price of base year value of final goods and services multiply by hundred percent (100\%).

External Debt Stock (EXDS): This refers to the financial resources which government, are using that are borrowed from the foreign countries other than the country own resource. It is also known as any kind of business funding acquired from sources outside the country whether it is borrowing from Bank, investments from private individuals or investment firms. This will be measured by taking the natural log of external debt stock in Nigeria. 
Real Effective Exchange Rate (EXR) (Control Variable): Real effective exchange rate is the nominal effective exchange rate (a measure of the value of a currency against a weighted average of several foreign currencies) divided by a price deflator or index of costs.

Real interest rate (INT) (Control Variable): Real interest rate is the lending interest rate adjusted for inflation as measured by the GDP deflator.

\subsection{Model Specification}

The hypotheses were stated with the aim of determining the impact of external debt stock on economic growth in Nigeria. The functional form of the model is as expressed below:

GDPGR = F(EXDS, DSV, EXR, INT)

Equ. (1) can be rewritten and expanded as follows:

$\mathrm{GDPGR}_{\mathrm{t}}=\beta_{0}+\beta_{1} \mathrm{EXDSS}_{\mathrm{t}}+\beta_{2} \mathrm{DSV}_{\mathrm{t}}+\beta_{3} \mathrm{EXR}_{\mathrm{t}}+\beta_{4} \mathrm{INT}_{\mathrm{t}} \varepsilon_{\mathrm{t}}$

Where $t$ denotes time,

$\begin{array}{lll}\text { GDPGR } & = & \text { GDP growth rate } \\ \text { EXDS } & = & \text { External debt stock }(\% \text { of GDP) } \\ \text { DSV } & = & \text { External debt services } \% \text { of GDP) } \\ \text { EXR } & = & \text { Real effective exchange rate } \\ \text { INT } & = & \text { Real interest rate } \\ \beta_{0} & = & \text { intercept } \\ \beta_{1-} \beta_{4} & = & \text { Coefficients } \\ \varepsilon & = & \text { Error term }\end{array}$

\section{RESULTS AND DISCUSSION}

\subsection{Descriptive Results}

Table 1 Descriptive Statistics

\begin{tabular}{|l|c|l|l|l|l|}
\hline Stat. & GDPGR & EXDS & DSV & EXR & INT \\
\hline Mean & 5.046588 & 0.658151 & 0.771950 & 121.4055 & 2.399785 \\
\hline Median & 5.487793 & 0.443586 & 0.364055 & 96.32562 & 4.997936 \\
\hline Maximum & 14.60438 & 2.319812 & 4.506193 & 486.7959 & 18.18000 \\
\hline Minimum & -1.583065 & 0.026146 & 0.006891 & 50.16845 & -31.45257 \\
\hline Std. Dev. & 3.833747 & 0.667177 & 1.050502 & 85.40609 & 10.22963 \\
\hline Skewness & 0.332086 & 0.966622 & 1.836426 & 2.755319 & -1.138522 \\
\hline Kurtosis & 2.606467 & 3.000050 & 6.368179 & 11.25238 & 4.896174 \\
\hline Jarque-Bera & 0.819491 & 5.294694 & 33.11263 & 139.4976 & 12.43891 \\
\hline Probability & 0.663819 & 0.070839 & 0.000000 & 0.000000 & 0.001990 \\
\hline Sum & 166.5374 & 22.37712 & 24.70241 & 4127.786 & 81.59270 \\
\hline Sum Sq. Dev. & 470.3237 & 14.68914 & 34.21021 & 240708.6 & 3453.296 \\
\hline Observations & 34 & 34 & 34 & 34 & 34 \\
\hline
\end{tabular}

Source: Researcher's Computation, 2020.

Table 1 explains the statistical descriptions of the variables in our model. The results revealed that GDPGR averaged 5.05\% while the external debt stock to GDP (EXDS) averaged $0.66 \%$. The mean of external debt services as a share of GDP (DSV) was $0.77 \%$. The Maximum GDPGR for Nigeria was $14.60 \%$ but lowest at $-1.58 \%$. The exchange rate (EXR) ranged between 50.16845 and 486.7959 to the dollar over the period 1985-2018. The results also showed that GDPGR and EXDS are normally distributed which is indicated by the p-value of the Jarque-Bera (J-B) statistics all of which are less than 5\%. However, DSV, EXR and INT 
did not provide evidence of normal distribution, with the p-value of J-B statistics being less that $5 \%$.

\subsection{Stationarity Test}

Table 2 Unit Root Test Results

\begin{tabular}{|l|c|c|c|c|l|}
\hline Variable & $\begin{array}{c}\text { ADF- } \\
\text { Statistic }\end{array}$ & $\begin{array}{c}\mathbf{5 \%} \text { critical } \\
\text { value }\end{array}$ & P-value & $\begin{array}{c}\text { Order of } \\
\text { Integration }\end{array}$ & Inference \\
\hline GDPGR & -6.45637 & -3.746465 & 0.0000 & $\mathrm{I}(1)$ & Stationary \\
\hline EXDS & -6.846535 & -3.465973 & 0.0001 & $\mathrm{I}(0)$ & Stationary \\
\hline DSV & -4.95635 & -3.766484 & 0.0200 & $\mathrm{I}(0)$ & Stationary \\
\hline EXR & -4.33987 & -3.766564 & 0.0001 & $\mathrm{I}(0)$ & Stationary \\
\hline INT & -4.09466 & -2.366580 & 0.0201 & $\mathrm{I}(0)$ & Stationary \\
\hline
\end{tabular}

Source: Researcher's Computation, 2020.

Results of the stationarity test in Table 2 show that our variables are stationary at different orders of integration. While EXDS, DSV, INT and EXR are stationary at level, I(0), GDPGR is stationary at first difference, $\mathrm{I}(1)$. Given that we have a mix of $\mathrm{I}(0)$ and $\mathrm{I}(1)$ in our stationarity test result, it becomes appropriate we employ the VAR technique in estimating our model.

Table 3 VAR Results

Dependent Variable: GGDPGR

Method: Least Squares (Gauss-Newton / Marquardt steps)

Sample (adjusted): 19862018

$\mathrm{GFCF}=\mathrm{C}(1) * \mathrm{GFCF}(-1)+\mathrm{C}(2) * \mathrm{MDS}(-1)+\mathrm{C}(3) * \mathrm{BDS}(-1)+$

$\mathrm{C}(4) * \operatorname{EXR}(-1)+$ $\mathrm{C}(5) * \operatorname{INT}(-1)+\mathrm{C}(6)$

\begin{tabular}{lllll}
\hline \hline & Coefficient & Std. Error & t-Statistic & Prob. \\
\hline \hline GDPGR(-1) & 0.844961 & 0.099286 & 8.510347 & 0.0000 \\
EXDS(-1) & -0.494723 & 2.137220 & -0.231480 & 0.0008 \\
DSV(-1) & -0.016559 & 0.895242 & -0.018497 & 0.0054 \\
EXR(-1) & 0.022768 & 0.010853 & 2.097924 & 0.0412 \\
INT(-1) & -0.162943 & 0.119066 & -1.368508 & 0.1833 \\
Intercept & 2.155549 & 2.470909 & 0.872371 & 0.3913 \\
\hline \hline R-squared & 0.904143 & Mean dependent var & 30.93136 \\
Adjusted R-squared & 0.884972 & S.D. dependent var & 13.59837 \\
S.E. of regression & 4.611991 & Akaike info criterion & 6.067182 \\
Sum squared resid & 531.7616 & Schwarz criterion & 6.344728 \\
Log likelihood & -88.04132 & Hannan-Quinn criter. & 6.157655 \\
F-statistic & 47.16125 & Durbin-Watson stat & 1.569131 \\
Prob(F-statistic) & 0.000000 & & & \\
\hline \hline
\end{tabular}

Regression estimates in Table 3 is based on VAR estimate where one period lag was selected by the lag selection criteria (see Table 4). The estimation results reveal that one period lag of economic growth (GDPGR) has positive and significant influence on current GDPGR. Moreover, the results show that both EXDS and DSV exert has negative and significant impact on economic growth. Similarly, we also observe that while EXR is positively and significantly related to the dependent variable, INT had negative and insignificant influence on the dependent variable. These outcomes entails that when EXDS changed by one-unit, GDPGR declined by 0.495 unit. On the other hand, when DSV changed by one-unit, GDPGR declined by 0.017 . The 
result also indicates that $1 \%$ change in the real effective exchange rate (EXR) lead to about 0.023 units increase in economic growth whereas $1 \%$ change in real interest rate (INT) led to about 0.163 units decline in economic growth. The coefficient of determination shows that the regressors account for about $90 \%$ of the variations in GDPGR while the remaining $10 \%$ could be attributed to other variables not included in the model. The results further indicated that the regressors jointly have significant effect on public investment as shown by the p-value of the F-statistic $(0.00000<0.05)$. The Durbin Watson statistic is also approximately 2.0 , thereby indicating that our model do not have autocorrelation problems.

\section{CONCLUSION}

This paper investigates the impact of external debt services on public investment in Nigeria from 1985 to 2018 using vector autoregressive (VAR) approach. We proxied economic growth by the GDP growth rate. The empirical results reveal that both external debt stock and external debt service exert a negative and significant impact on economic growth. These outcomes entails that when multilateral debt services changed by one-unit, economic growth declined by 0.495 unit. On the other hand, when external debt services changed by one-unit, economic growth declined by 0.017 unit. We conclude that external debt stock has been an impediment to economic growth in Nigeria over the period under study. We therefore recommend that policy makers should adhere strictly to the appropriate use of debt through efficient investment to foster growth and avoid excessive debt accumulation.

\section{REFERENCES}

[1] Adofu, I. \& Abula, M. (2010). Domestic Debt and the Nigerian Economy. Current Research Journal of Economic Theory, 2(1):22-26

[2] Akhanolu, I. A.; Babajide, A. A.; Akinjare, V.; Oladeji, T. \& Osuma, G. (2018). The Effect of Public Debt on Economic Growth in Nigeria: An Empirical Investigation, International Business Management 12 (6): 436-441.

[3] Al-Refai (2015). Debt and economic growth in developing countries: Jordan as a study. International Journal of Economics and Finance; 7(3):81-98.

[4] Al-Zeaud, H. A. (2014). Public Debt and Economic Growth: An Empirical Assessment, European Scientific Journal, 10(4): 148-158

[5] Balassone, F. \& Francese. M. (2011) Pace A. Public debt and economic growth in Italy. Economic History, Working Papers no. 11, Banca d'Italia.

[6] Barik, A. (2013). Government Debt and Economic Growthin India; Centre for Economic Studies and Planning; New Delhi

[7] Checherita, H. \&, Rother, P. (2010). The impact of high and growing government debt on economic growth: An empirical investigation for the Euro Area. IMF Working Paper No. $10 / 1237$.

[8] Checherita, H \& Rother, J. (2010). Domestic Debt, Credit Rationing and Investment, Journal of Development Economics, 2,(1): 12-20.

[9] Egbetunde, T., (2012). Public Debt and Economic growth in Nigeria: Evidence from granger causality, America journal of Economics 2(6): 101-106. 
[10] Égert, B. (2015). Public Debt, Economic Growth and Nonlinear Effects: Myth or Reality? Journal of Macroeconomics, 43: 226-238.

[11] Ekperiware, M.C. \& Oladeji, S.I. (2012). External Debt Relief and Economic Growth in Nigeria: 1975-2005. American Journal of Economics, 2(7).

[12] El-Mahdy, M. A. \& Torayeh, M. N. (2009). Debt sustainability and economic growth in Egypt. International Journal of Applied Econometrics and Quantitative Studies. 6(1):21-55.

[13] Elmendorf, D. \& Mankiw, N. G. (1999). Government Debt, in J. B. Taylor and M. Woodford (eds.), Handbook of Macroeconomics, Vol. 1C, Amsterdam, North-Holland.

[14] Elom-Obed, O. F.; Odo, S. I.; Elom-Obed, O.; \& Anoke, C. I. (2017). Public Debt and Economic Growth in Nigeria, Asian Research Journal of Arts \& Social Sciences, 4(3): 1-16.

[15] Herndon, T.; Ash, M. \& Pollin, R. (2014). Does high public debt consistently stifle economic growth? A critique of Reinhart and Rogof, Cambridge Journal of Economics. 38(2):257-79.

[16] Hussain, M. E.; Haque, M. \& Igwike, R. (2015). Relationship between economic growth and debt: An empirical analysis for Sub-Saharan Africa. Journal of Economics and Political Economy. 2(2):262-276.

[17] IMF (2016). International monetary fund report. No. 16/277. International Monetary Fund

[18] Irina, B. \& Iulian, I. (2015). Public Debt and Economic Growth: A Two-Sided Story, International Journal of Economic Sciences, 4(2): 24-39

[19] Karagol, E. (2002). The Causality Analysis of External Debt Service and GNP: The Case of Turkey, Central Bank Review, 2(1): 39-64.

[20] Kaur, A. \& Kaur, B. (2015). The Effects of Public Debt on Economic Growth and Gross Investment in India: An Empirical Evidence, Pacific Business Review International, 8(1): 5056

[21] Kourtellos, A.; Stengos, T. \& Tan, C. M. (2013). The Effect of Public Debt on Growth in Multiple Regimes, Journal of Macroeconomics, 38:35-43.

[22] Krugman, P., 1988. Financing Versus Forgiving a debt overhang: Some analytical notes. Journal of Development Economics, 29: 253-268.

[23] Kumar, M. S \& Woo, J. (2010). Public Debt and Growth, IMF working paper, WP/10/174.

[24] Lin, S. \& Sosin, K. (2001). Foreign debt and economic growth. Economics of Transition. 9(3):635-665

[25] Lin, S. (2000). Government debt and economic growth in an overlapping generations model. Southern Economic Journal. 66(3):754-763.

[26] Lof, M. \& Malinen, T (2014). Does Sovereign Debt Weaken Economic Growth? A Panel VAR Analysis, Economics Letters, 122(3): 403-407.

[27] Love, I. \& Zicchino, L. (2006). Financial Development and Dynamic Investment Behavior: Evidence from Panel VAR, The Quarterly Review of Economics and Finance, 46(2): 190-210.

[28] Puente-Ajovín, M. \& Sanso-Navarro, M. (2015). Granger Causality between Debt and Growth: Evidence from OECD Countries, International Review of Economics and Finance, 35:66-77. 
[29] Putanoi, G. K \& Mutuku, C. M., (2013). Domestic Debt and Economic Growth Nexus in Kenya, Current Research Journal of Economic theory 5(1): 1-10.

[30] Reinhart, C. M. \& Rogoff, K. S. (2010). Growth in a Time of Debt, American Economic Review, 100(2): 573-578.

[31] Reinhart, C. M. \& Rogoff, K. S. (2011), From Financial Crash to Debt Crisis, American Economic Review, 101(5): 1676-1706.

[32] Reinhart, C., \& Rogoff, K. (2009), The Aftermath of Financial Crises, American Economic Review, 99(2): 466-472.

[33] Spilioti, S. (2015). The relationship between the government debt and GDP growth: Evidence of the Euro area countries. Investment Management and Financial Innovations, 12(1-1): 174178

[34] Tajudeen, E. (2012). Public Debt and Economic Growth in Nigeria: Evidence from Granger Causality; American Journal of Economics, 2(6): 101-106

[35] Tchereni, B.H.M.; Sekhampu, T. J. \& Ndovi, R. F. (2013). The impact of foreign debt on economic growth in Malawi. African Development Review. 25(1):85-90. the National Debt, Economic Journal, 71(284):730-755.

[36] Tunde, E. T. (2012). Public debt and economic growth in Nigeria: Evidence from Granger Causality. American Journal of Economics. 2(6). 